\title{
Calcium Transport in the Pars Recta and Thin Descending Limb of Henle of the Rabbit, Perfused In Vitro
}

\author{
D. Rouse, R. C. K. NG, and W. N. SukI, Renal Section, Department of Medicine, \\ Baylor College of Medicine, and The Methodist Hospital, \\ Houston, Texas 77030
}

A B S T R A C T Unidirectional calcium flux $\left(\mathrm{J}^{\mathrm{c} a}\right)$ in the superficial pars recta and thin descending limb of Henle (DLH) was examined by the isolated tubule microperfusion technic using ${ }^{45} \mathrm{Ca}$ as the isotopic tracer.

In the pars recta sequential measurements of lumen-to-bath flux $\left(\mathrm{J}_{1 \mathrm{~b}}^{\mathrm{Ca}}\right)$ and bath-to-lumen flux $\left(\mathrm{J}_{\mathrm{bl}}^{\mathrm{Ca}}\right)$ revealed: $\mathrm{J}_{1 \mathrm{~b}}^{\mathrm{a}} 22.4 \pm 4.18, \quad \mathrm{~J}_{\mathrm{bl}}^{\mathrm{Ca}} 7.97 \pm 1.95$, and calculated net efflux of calcium ( $\left.\mathrm{J}_{\text {net }}^{\mathrm{Ca}}\right) 13.0 \pm 1.74$ peq $\mathrm{min}^{-1} \mathrm{~mm}^{-1}$. To measure $\mathrm{J}_{\text {net }}^{\mathrm{Ca}}$ directly, ${ }^{45} \mathrm{Ca}$ of identical specific activity was used to bathe and perfuse the tubule. These studies revealed: $\mathrm{J}_{\mathrm{lb}}^{\mathrm{Ca}} 14.1 \pm 1.33$, $\mathrm{J}_{\text {net }}^{\mathrm{Ca}} 11.2 \pm 1.15$, and calculated $\mathrm{J}_{\mathrm{bl}}^{\mathrm{ca}} 2.91 \pm 0.49$ peq $\min ^{-1} \mathrm{~mm}^{-1}$. The addition of ouabain $(10 \mu \mathrm{M})$ resulted in a rise in potential difference and a fall in water absorption, but not a statistically significant change in $\mathrm{J}_{\text {net }}^{\mathrm{Ca}}$. Tubules studied at $25^{\circ} \mathrm{C}$ bath temperature, showed no significant $\mathrm{J}_{\text {net }}^{\mathrm{Ca}}$, and upon heating the bath to $37^{\circ} \mathrm{C}$, showed $\mathrm{J}_{\text {net }}^{\mathrm{Ca}}$ of $3.75-5.00$ peq $\mathrm{min}^{-1}$ $\mathrm{mm}^{-1}$. Unidirectional and net efflux studies in six DLH showed no significant transport of calcium.

These studies demonstrate substantial active absorption of calcium by the superficial pars recta, which is not inhibitable by ouabain but is inhibited by lowering bath temperature to $25^{\circ} \mathrm{C}$. No significant calcium transport was found in the DLH using identical technics.

\section{INTRODUCTION}

Micropuncture studies have shown that $20-35 \%$ of the filtered calcium is absorbed between the late

Preliminary reports of this work were presented at the Annual Meeting of The American Society for Clinical Investigation, San Francisco, Calif., May 1978, and at the VIIth International Congress of Nephrology, Montreal, Canada, June 1978.

Dr. Ng was a postdoctoral Fellow of the National Kidney Foundation during the course of these studies.

Received for publication 9 April 1979 and in revised form 20 August 1979. proximal convoluted tubule and the early distal convoluted tubule (1). Calcium absorption in the loop of Henle had been attributed to the thick ascending limb, and recent isolated tubule microperfusion studies have confirmed the presence of significant calcium transport in this segment $(2-4)$.

Jamison et al. (5), in micropuncture studies in rats, showed that the fractions of filtered sodium and calcium remaining in the late proximal convoluted tubule were similar, being 56 and $60 \%$, respectively. Samples from the bend of the loop of Henle, however, showed a dissociation of sodium and calcium delivery, being 43 and $32 \%$ of their respective filtered loads. Similar discrepancy in the delivery of calcium and sodium to the bend of Henle's loop has been described in Psammomys (6). These two studies suggest absorption of calcium in excess of sodium at a site between the end of the proximal convoluted tubule and the bend of the loop of Henle. The thin descending limb has been shown to possess a low permeability to calcium (2) and would not be expected to serve such a function. Because the pars recta has been shown to transport significant amounts of sodium and chloride (7-9) as well as certain organic compounds $(10-12)$, the present studies were designed to examine the superficial pars recta as the possible site for calcium absorption.

\section{METHODS}

Studies were performed on normal female New Zealand white rabbits, weighing $1.5-2.5 \mathrm{~kg}$, maintained on standard rabbit chow and allowed free access to water. Immediately after sacrifice by guillotine, the left kidney was removed and decapsulated. 1-mm thick transverse sections were removed and transferred to a dish of chilled rabbit serum (Microbiological Associates, Walkersville, Md.). Single segments of superficial pars recta were dissected with careful attention to anatomical location, transferred to a Lucite perfusion chamber, and perfused according to the method of Burg et al. (13) within 30 min after sacrifice. A 50 -meq/liter $\mathrm{NaCl}$ gradient (bath < lumen) was imposed and a positive potential of at least $3 \mathrm{mV}$ was taken as evidence that the tubule was super- 
ficial in origin. ${ }^{1}$ All solutions were equilibrated with $5 \%$ $\mathrm{CO}_{2}$ and $95 \% \mathrm{O}_{2}$ gas mixture to maintain a pH of 7.4. Except for tubules studied at room temperature, the bath was heated to $37^{\circ} \mathrm{C}$ within $5 \mathrm{~min}$ after transfer of the tubule into the perfusion chamber and maintained at $37^{\circ} \mathrm{C}$ throughout perfusion. The tubules were allowed to equilibrate for 45-60 min before control collections were made. Transtubular potential difference $(P D)^{2}$ was measured using agarose-Ringer's bridges and calomel half-cells (Beckman Instruments, Inc., Fullerton, Calif.) as described by Kokko and Rocha $(15,16)$. Water absorption (Jv) was measured using exhaustively dialyzed (8) [methoxy- ${ }^{3} \mathrm{H}$ ]inulin (New England Nuclear, Boston, Mass.). $100 \mu \mathrm{Ci}$ of inulin were delivered into a plastic tube and the water vehicle evaporated with a gentle stream of $100 \%$ nitrogen; 3-5 ml of perfusion solution was then added and mixed thoroughly. Calcium flux $\left(\mathrm{J}^{\mathrm{Ca}}\right)$ was measured with ${ }^{45} \mathrm{CaCl}_{2}$ (New England Nuclear). To each milliliter of rabbit serum or serum ultrafiltrate was added $2.5-10.0 \mu \mathrm{Ci}$ of ${ }^{45} \mathrm{Ca}$. The specific activity of ${ }^{45} \mathrm{Ca}$ was $20-30 \mathrm{Ci} / \mathrm{g}$, and the quantity of isotope added must have increased the concentration of calcium in the serum or ultrafiltrate by only $0.15-0.7 \%$.

Timed fluid collections were made under a layer of oil with calibrated constant-volume constriction pipettes. The samples were discharged into counting vials containing $1 \mathrm{ml}$ of water; $10 \mathrm{ml}$ of Instagel (Parkard Instrument Co., Downers Grove, IIl.) was added and each vial shaken vigorously. Isotopic concentrations were determined in a well liquid-scintillation spectrometer (Packard Instrument).

Because of the tendency for calcium to bind to glass, all pipettes in contact with the perfusion solution and the collected fluid were siliconized. The glass was treated with a 6\% solution of SC-87 (Pierce Chemical Co., Rockford, Ill.) in chloroform, flushed with toluene, and air dried.

In all experiments rabbit serum ultrafiltrate, prepared with Centriflo CF50 membranes (Amicon Corp. Scientific Sys. Div., Lexington, Mass.), was used as perfusate and whole rabbit serum as the bathing medium. Changes in concentration of bath constituents caused by evaporative water loss were prevented by the constant addition of fresh bathing medium at the rate of $0.5 \mathrm{ml} / \mathrm{min}$, so that the entire bath volume was replaced every 3-4 $\mathrm{min}$. Chemical calcium concentration was determined for each batch of rabbit serum and ultrafiltrate by an atomic absorption spectrophotometer (Instrumentation Laboratories, Inc., Lexington, Mass.). For different batches the serum calcium ranged from 5.65 to $6.00 \mathrm{meq} / \mathrm{liter}$ and the ultrafilterable calcium ranged from 3.2 to $4.0 \mathrm{meq} / \mathrm{liter}$.

Five types of experiments were performed:

The first type was designed to measure lumen-to-bath (lb) and bath-to-lumen (bl) flux sequentially. For lb (efflux) measurements ${ }^{45} \mathrm{Ca}$ was added to the perfusate with the volume marker. For bl measurements the perfusate contained only the volume marker, and the bath contained ${ }^{45} \mathrm{Ca}$. The order was alternated within an experiment and from one experiment to the next. At least $30 \mathrm{~min}$ were allowed between changes in bath or perfusate.

The second type of experiment used lb measurements and net efflux measurements. For measurement of net efflux the specific activity of ${ }^{45} \mathrm{Ca}$ was identical in the lumen and the bath. This was achieved by the addition of ${ }^{45} \mathrm{Ca}$ to $150-\mathrm{ml}$ of rabbit

\footnotetext{
${ }^{1}$ Kawamura et al. (14) accomplished this maneuver by diluting the bath with a $\mathrm{NaCl}$-free solution of sucrose. In our experiments, raffinose was used in place of sucrose. The liquid junction potential resulting from this maneuver has been calculated to be $+2.46 \mathrm{mV}$.

${ }^{2}$ Abbreviations used in this paper: bl, bath-to-lumen; $\mathrm{J}^{\mathrm{ca}}$ and $J_{\text {net }}^{\mathrm{Ca}}$, calcium flux and net calcium efflux; Jv, water absorption; lb, lumen-to-bath; PD, potential difference.
}

serum, and the serum allowed to equilibrate overnight. On the morning of the experiment, a 10-ml aliquot of the serum containing ${ }^{45} \mathrm{Ca}$ was ultrafiltered and the ultrafiltrate used as perfusate. The remaining $140 \mathrm{ml}$ was used to bathe the tubule during the measurements of net efflux.

In the third type of experiment, control net efflux measurements were made followed by the addition of ouabain $(10 \mu \mathrm{M})$ to the bath. After 15-20 min, three to four collections were made, ouabain was removed, 30-45 min allowed for recovery, and three more collections made.

In the fourth type of experiment, two to three net efflux measurements were made at $25^{\circ} \mathrm{C}$ bath temperature. The bath was then heated to $37^{\circ} \mathrm{C}$, and net efflux measurements repeated at intervals over a 2 -h period.

In the fifth type of experiment, unidirectional and net effluxes were measured, as in group two, in thin descending limbs of Henle. Positive identification was made by observing the transition from pars recta to the thin descending limb of Henle.

\section{Calculations}

$\mathrm{Jv}$ (nanoliters per minute per millimeter) was calculated as follows:

$$
\mathrm{Jv}=\left(\frac{\mathrm{Vi}-\mathrm{Vo}_{\mathrm{o}}}{\mathrm{L}}\right),
$$

where $\mathrm{Vi}$ is the rate of perfusion (nanoliters per minute), Vo is the rate of fluid collection (nanoliters per minute) and $\mathrm{L}$ is the tubule length (millimeter). J Ca (picoequivalent per minute per millimeter) and $\mathrm{J}_{\mathrm{b} 1}^{\mathrm{Ca}}$ (picoequivalent per minute per millimeter) were calculated by the following mass balance formulas:

and

$$
\mathrm{J}_{\mathrm{ib}}^{\mathrm{Ca}}=\left(\frac{\mathrm{ViCi}-\mathrm{VoCo}}{\mathrm{L}}\right)\left(\frac{[\mathrm{Ca}] \mathrm{i}}{\mathrm{Ci}}\right)
$$

$$
\mathrm{J}_{\mathrm{bl}}^{\mathrm{Ca}}=\left(\frac{\mathrm{VoCo}}{\mathrm{L}}\right)\left(\frac{[\mathrm{Ca}] \mathrm{b}}{\mathrm{Cb}}\right) \text {, }
$$

where $\mathrm{Ci}, \mathrm{Co}$, and $\mathrm{Cb}$ are the ${ }^{45} \mathrm{Ca}$ counts per minute per nanoliter in the perfusate, collected sample, and bath, respectively; and [Ca]i and [Ca]b the chemical calcium concentration in the perfusate and bath, respectively. ${ }^{3}$ These formulas yielded flux values not different from values calculated from the formula $\mathrm{J}=\mathrm{K} \times \overline{\mathrm{C}}$, where $\mathrm{K}$ is flux coefficient and $\bar{C}$ is mean luminal concentration. Net efflux of calcium $\left(\mathrm{J}_{\text {net }}^{\mathrm{Ca}}\right)$ was calculated in the same fashion as $\mathrm{J}_{\mathrm{lb}}^{\mathrm{Ca}}$ (Eq. 2). The tubule length was measured with a reticle in the eyepiece of the microscope. Efflux $\left(\mathrm{Ke}^{\mathrm{Ca}}\right)$ and influx $\left(\mathrm{Ki}^{\mathrm{Ca}}\right)$ coefficients were calculated by the following formulas (2):

and

$$
\mathrm{Ke}^{\mathrm{Ca}}=\left(\frac{\mathrm{Vi}-\mathrm{Vo}}{\mathrm{A}}\right)\left(\frac{\ln \mathrm{Ci} / \mathrm{Co}}{\ln \mathrm{Vi} / \mathrm{Vo}}+1\right)
$$

$$
\mathrm{Ki}^{\mathrm{Ca}}=\left(\frac{\mathrm{Co}}{\mathrm{Cb}}\right)\left(\frac{\mathrm{Ke}}{1-\mathrm{e}^{(\mathrm{AKe} / \overline{\mathrm{V}})}}\right),
$$

${ }^{3}$ In Eqs. 2 and 3 the terms [Ca]i/Ci and [Ca]b/Cb are specific activity terms relating mass units to counts per minute. Because in the case of rabbit serum (bath) ${ }^{45} \mathrm{Ca}$ has equilibrated completely with the total pool of cold calcium, the specific activity of calcium in whole serum and in serum ultrafiltrate was equal, i.e., $[\mathrm{Ca}] \mathrm{i} / \mathrm{Ci}=[\mathrm{Ca}] \mathrm{b} / \mathrm{Cb}$. 
where $A$ is the area of the tubule calculated from the measured length and the inside diameter of the tubule, and $\overline{\mathrm{V}}$ is $\mathrm{Vi}+\mathrm{V}_{\mathrm{o}} / 2$.

Statistical analysis was performed by paired $t$ statistic, $t$ statistic, or analysis of variance as indicated.

\section{RESULTS}

$J_{b b}^{c a}$ and $J_{b l}^{C a}$. The results for the six tubules in this group are summarized in Table I. Because the perfusate used for the bl flux measurements contained only $\left[{ }^{3} \mathrm{H}\right]$ inulin, a high perfusion rate (mean of 28.5

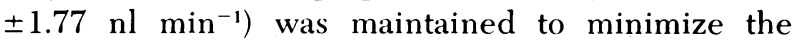
specific activity of ${ }^{45} \mathrm{Ca}$ entering the tubule lumen. The rate of perfusion for the $\mathrm{lb}$ measurements was comparable $\left(27.9 \pm 1.84 \mathrm{nl} \mathrm{min}^{-1}\right)$. The ratio of the specific activity of ${ }^{45} \mathrm{Ca}$ in the collected fluid vs. the bath ranged from 0.04 to 0.23 (mean of 0.12 ). Jv was $0.59 \pm 0.12 \mathrm{nl}$ $\mathrm{min}^{-1} \mathrm{~mm}^{-1}$ for bl measurements and $0.39 \pm 0.05 \mathrm{nl}$ $\mathrm{min}^{-1} \mathrm{~mm}^{-1}$ for $\mathrm{lb}$ measurements; the difference is not statistically significant by paired $t$ statistic. PD was also comparable: $\mathrm{bl}-0.83 \pm 0.14 \mathrm{mV}$ and $\mathrm{lb}-0.56 \pm 0.11$ $\mathrm{mV}$. The mean $\mathrm{J}_{\mathrm{bl}}^{\mathrm{Ca}}$ was $7.97 \pm 2.75$ peq $\mathrm{min}^{-1} \mathrm{~mm}^{-1}$ and $\mathrm{J}_{1 \mathrm{~b}}^{\mathrm{Ca}}$ was $22.4 \pm 4.18$ peq $\mathrm{min}^{-1} \mathrm{~mm}^{-1}$, giving a mean calculated net efflux of $13.0 \pm 1.74$ peq $\mathrm{min}^{-1}$ $\mathrm{mm}^{-1}$. The flux coefficients were $\mathrm{Ki}^{\mathrm{Ca}} 4.20 \pm 1.44 \times 10^{-5}$ $\mathrm{cm} \mathrm{s}{ }^{-1}$ and $\mathrm{Ke}^{\mathrm{Ca}} 13.4 \pm 2.13 \times 10^{-5} \mathrm{~cm} \mathrm{~s}^{-1}$.

$J_{l b}^{c a}$ and $J_{\text {net. }}^{c a}$. Table II summarizes the results for five tubules. Perfusion rate for these studies was 21.9 $\pm 2.45 \mathrm{nl} \mathrm{min}^{-1}$ for unidirectional efflux measurements


$\mathrm{Jv}$ and PD were also comparable for unidirectional and net efflux measurements. $\mathrm{J}_{\mathrm{lb}}^{\mathrm{Ca}}$ was $14.1 \pm 1.33$ peq $\min ^{-1} \mathrm{~mm}^{-1}$ and $\mathrm{J}_{\text {net }}^{\mathrm{Ca}}$ was $11.2 \pm 1.15$ peq $\min ^{-1} \mathrm{~mm}^{-1}$. The mean calculated $\mathrm{J}_{\mathrm{bl}}^{\mathrm{ca}}$ was $2.91 \pm 0.49$ peq $\mathrm{min}^{-1}$ $\mathrm{mm}^{-1}$. None of these values is significantly different from corresponding values in the previous set of data. The maximum passive movement of calcium caused by $\mathrm{Jv}(\mathrm{Jv} \times[\mathrm{Ca}] \mathrm{i})$ was calculated to be $3.01 \pm 0.06 \mathrm{peq}$ $\mathrm{min}^{-1} \mathrm{~mm}^{-1}$, leaving a substantial $\mathrm{J}_{\text {net }}^{\mathrm{ca}}$ not attributable to sodium and Jv.

For the net efflux measurements the ratio of the concentration of ${ }^{45} \mathrm{Ca}$ collected to the concentration per-

TABLE I

Unidirectional Flux of ${ }^{45} \mathrm{Ca}$ in the Superficial Pars Recta

\begin{tabular}{lcccc}
\hline & Perfusion rate & $\mathrm{Jv}$ & $\mathrm{J}^{\mathrm{Ca}}$ & $\mathrm{PD}$ \\
\hline & $n l \min ^{-1}$ & $n l m$ in $^{-1} \mathrm{~mm}^{-1}$ & peq $\min ^{-1} \mathrm{~mm}^{-1}$ & $m \mathrm{mV}$ \\
$\mathrm{lb}$ & 27.9 & 0.39 & 22.4 & -0.56 \\
$\mathrm{SEM}$ & 1.84 & 0.05 & 4.18 & 0.11 \\
$\mathrm{bl}$ & 28.5 & 0.59 & 7.97 & -0.83 \\
$\mathrm{SEM}$ & 1.77 & 0.12 & 2.95 & 0.14 \\
$P$ & $\mathrm{NS}$ & $\mathrm{NS}$ & $<0.020$ & $\mathrm{NS}$ \\
\hline
\end{tabular}

$n=6$ tubules; mean length $=1.67 \pm 0.13 \mathrm{~mm}$.
TABLE II

Unidirectional and $J_{n e t}^{c a}$ in the Superficial Pars Recta

\begin{tabular}{lcccc}
\hline & $\begin{array}{c}\text { Perfusion } \\
\text { rate }\end{array}$ & $\mathrm{Jv}$ & $\mathrm{J}^{\text {'a }}$ & $\mathrm{PD}$ \\
\hline & $n l \mathrm{~min}^{-1}$ & $\begin{array}{c}n l \mathrm{~min}^{-1} \\
\mathrm{~mm}^{-1}\end{array}$ & $\begin{array}{c}\text { peq } \mathrm{min}^{-1} \\
\mathrm{~mm}^{-1}\end{array}$ & $m V$ \\
Unidirectional & & & & \\
$\quad$ (lb) & 21.9 & 0.70 & 14.1 & -1.06 \\
SEM & 2.45 & 0.15 & 1.33 & 0.32 \\
Net & & & & \\
(lb) & 22.3 & 0.53 & 11.2 & -1.22 \\
SEM & 1.95 & 0.18 & 1.15 & 0.24 \\
$P$ & $\mathrm{NS}$ & $\mathrm{NS}$ & $<0.005$ & $\mathrm{NS}$ \\
\hline
\end{tabular}

$n=5$ tubules; mean length $=1.70 \pm 0.10 \mathrm{~mm}$.

fused was always $<1.0$ and averaged $0.82 \pm 0.11$ (Fig. 1). The ratio of $\left[{ }^{3} \mathrm{H}\right]$ inulin concentration collected to that perfused was $1.04 \pm 0.01$ for the same measurements. The generation of a chemical gradient between lumen and bath in the face of a lumen-negative PD $(-1.22 \mathrm{mV})$ suggests an active mechanism for calcium absorption in this segment.

Effect of perfusion rate on $J_{\text {net }}^{C a}$. Fig. 2 depicts the relationship of $\mathrm{J}_{\text {net }}^{\mathrm{ca}}$ to perfusion rate. The amount of calcium absorbed is directly proportional to the delivered load. The regression equation for this relationship is $y=0.39 x+1.35$, and the correlation coefficient $(r)$ is $0.60(P<0.001)$ for individual periods from 20 different tubules. When values from individual tubules were averaged and plotted, the same general relationship was obtained: $y=0.41 x+0.81, r=0.54(P<0.02)$.

Effect of ouabain on $J_{\text {net }}^{c a}$. Table III summarizes the results for the five tubules in this group. Perfusion rate did not vary significantly from control (27.6 $\pm 2.46 \mathrm{nl} \mathrm{min}-1)$, to ouabain $\left(24.2 \pm 1.94 \mathrm{nl} \mathrm{min}^{-1}\right)$, to recovery $\left(30.6 \pm 1.39 \mathrm{nl} \mathrm{m^{-1 }}\right)$. Jv fell from control, $0.62 \pm 0.10 \mathrm{nl} \mathrm{min}^{-1} \mathrm{~mm}^{-1}$, to $0.04 \pm 0.04 \mathrm{nl} \mathrm{min}^{-1} \mathrm{~mm}^{-1}$ with ouabain, and recovered to $0.43 \pm 0.06 \mathrm{nl} \mathrm{min}^{-1}$ $\mathrm{mm}^{-1}$ with the removal of ouabain. PD rose from control, $-1.30 \pm 0.20 \mathrm{mV}$ to $-0.25 \pm 0.11 \mathrm{mV}$ with ouabain,
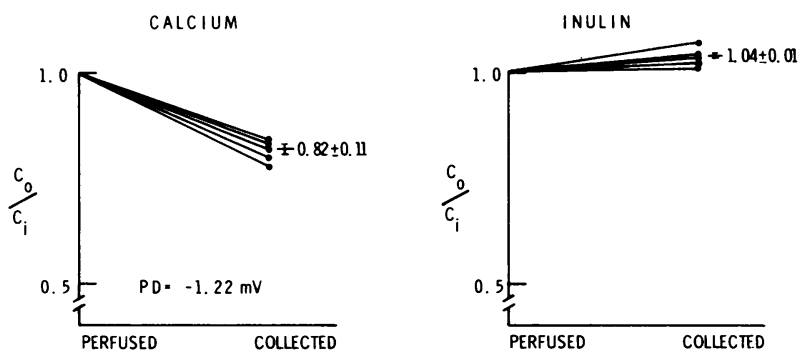

Figure 1. The ratio of ${ }^{45} \mathrm{Ca}$ collected $(\mathrm{Co})$ to ${ }^{45} \mathrm{Ca}$ perfused (Ci) (left panel), and the ratio of $\left[{ }^{3} \mathrm{H}\right]$ inulin collected to perfused (right panel), in experiments with perfusate and bath of identical ${ }^{45} \mathrm{Ca}$ specific activity. 


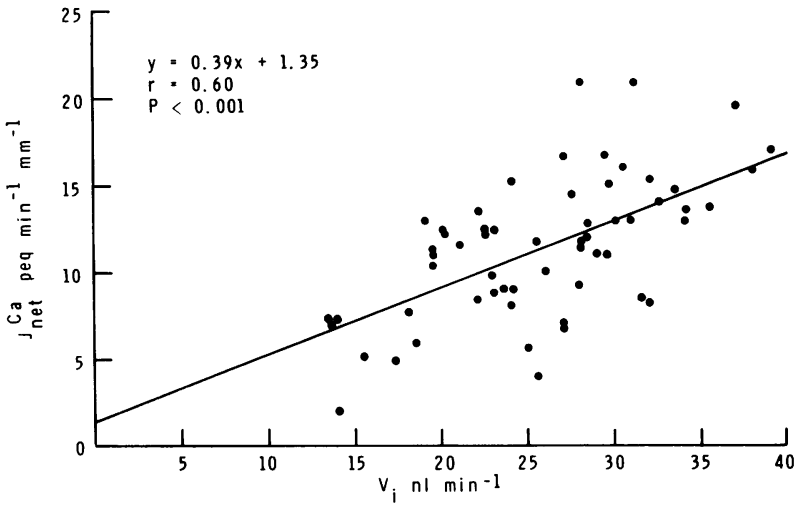

FIGURE 2. The relationship of $J_{\text {net }}^{\text {ca }}$ to perfusion rate $\left(V_{i}\right)$.

and recovered partially with the removal of ouabain to $-0.81 \pm 0.12 \mathrm{mV}$. Although $\mathrm{J}_{\text {net }}^{\mathrm{Ca}}$ fell from $12.4 \pm 1.21$ peq $\mathrm{min}^{-1} \mathrm{~mm}^{-1}$ in control to $10.8 \pm 0.91 \mathrm{peq} \mathrm{min}^{-1}$ $\mathrm{mm}^{-1}$ during ouabain, and recovered to $14.0 \pm 1.28 \mathrm{peq}$ $\mathrm{min}^{-1} \mathrm{~mm}^{-1}$, the changes were not statistically significant by analysis of variance.

Effect of cold on $J_{\text {net }}^{c a}$. The results of three tubules studied at $25^{\circ} \mathrm{C}$ bath temperature are illustrated in Fig. 3; Jnet was between -3.00 and +0.04 peq min $^{-1}$ $\mathrm{mm}^{-1}$. The $\mathrm{J}_{\text {net }}^{\mathrm{Ca}}$ rose steadily to $3.75-5.00$ peq $\mathrm{min}^{-1}$ $\mathrm{mm}^{-1} 2 \mathrm{~h}$ after the bath was heated to $37^{\circ} \mathrm{C}$. The mean $\mathrm{Jv}$ for periods collected at $25^{\circ} \mathrm{C}$ was $0.12 \pm 0.11 \mathrm{nl} \mathrm{min}^{-1}$ $\mathrm{mm}^{-1}$ and $0.13 \pm 0.04 \mathrm{nl} \mathrm{min}{ }^{-1} \mathrm{~mm}^{-1}$ for periods collected at $37^{\circ} \mathrm{C}$. Thus, the increase in $\mathrm{J}_{\text {net }}^{\mathrm{ca}}$ could not be attributed to changes in Jv.

Studies of the thin descending limb of Henle. The mean length of six tubules was $1.29 \pm 0.08 \mathrm{~mm}$, and the

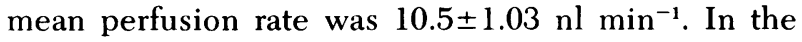

TABLE III

Effect of Ouabain $(10 \mu \mathrm{M})$ on $J_{n e t}^{c a}$ in the Superficial Pars Recta

\begin{tabular}{lcccc}
\hline & Perfusion rate & $\mathrm{Jv}$ & $\mathrm{J}^{\mathrm{a}}$ & $\mathrm{PD}$ \\
\hline & $n l \mathrm{~min}^{-1}$ & $\begin{array}{c}n l \mathrm{~min}^{-1} \\
\mathrm{~mm}^{-1}\end{array}$ & $\begin{array}{c}\text { peq } \min ^{-1} \\
\mathrm{~mm}^{-1}\end{array}$ & $\mathrm{mV}$ \\
Control & 27.6 & 0.62 & 12.4 & -1.30 \\
SEM & 2.46 & 0.10 & 1.21 & 0.20 \\
$\begin{array}{l}\text { Ouabain } \\
\text { SEM }\end{array}$ & 24.2 & 0.04 & 10.8 & -0.25 \\
$\begin{array}{l}\text { Recovery } \\
\text { SEM }\end{array}$ & 1.94 & 0.04 & 0.91 & 0.11 \\
$\begin{array}{l}P \text { control vs. } \\
\text { ouabain }\end{array}$ & 30.6 & 0.43 & 14.0 & -0.81 \\
$\begin{array}{l}P \text { control vs. } \\
\text { recovery }\end{array}$ & 1.39 & 0.06 & 1.28 & 0.12 \\
$\begin{array}{l}P \text { ouabain vs. } \\
\text { recovery }\end{array}$ & $\mathrm{NS}$ & $<0.005$ & $\mathrm{NS}$ & $<0.005$ \\
\hline & $\mathrm{NS}$ & $\mathrm{NS}$ & $\mathrm{NS}$ & $<0.050$ \\
\hline
\end{tabular}



Figure 3. The effect of cold and subsequent heating on, Jnet.

absence of an osmotic gradient, mean Jv was $0.10 \pm 0.07$

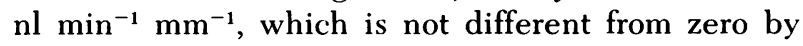
paired $t$ statistic. Similarly, $\mathrm{J}_{\mathrm{lb}}^{\mathrm{Ca}}$ was $1.18+0.83 \mathrm{peq}$ $\mathrm{min}^{-1} \mathrm{~mm}^{-1}$, and $\mathrm{J}_{\text {net }}^{\mathrm{Ca}}-0.07 \pm 0.39$ peq $\mathrm{min}^{-1} \mathrm{~mm}^{-1}$. Neither is statistically different from zero by paired $t$ testing. $\mathrm{Ke}^{\mathrm{Ca}}$ was $0.64 \pm 0.73 \times 10^{-5} \mathrm{~cm} \mathrm{~s}^{-1}$, a value comparable to that found by Rocha et al. (2).

\section{DISCUSSION}

It generally had been assumed that the thick ascending limb of Henle was responsible for the absorption of calcium between the end of the proximal convoluted tubule and the early distal convoluted tubule. However, micropuncture studies in the rat (5) and Psammomys (6) have suggested that calcium may be absorbed disproportionately to sodium before the bend of the loop of Henle. Because the thin descending limb had been shown to be relatively impermeable to calcium (2), these observations suggested that the proximal straight tubule may be an important site of calcium absorption. The present studies demonstrate a high degree of permeability to calcium in the superficial pars recta. Even though the PD was oriented negative in the lumen relative to the bath, a state which should have retarded efflux and enhanced backflux, calcium efflux was actually severalfold calcium backflux, resulting in a significant net efflux from this segment. Net calcium efflux did not appear to be saturated; instead, it increased progressively with the load, and it could be calculated that $9 \%$ of the load was absorbed per millimeter tubule length per minute. Neither the unidirectional nor the net efflux could be accounted for by Jv. In fact, assuming reflection coefficient of zero for calcium in this segment, the amount of calcium calculated to be removed with sodium and water is only a fraction of the measured calcium efflux. Consequently, the ratio of the concentration of calcium 
in the collected fluid to that in the perfusate was 0.82 . The demonstration that calcium can be transported against an electrical and a chemical gradient indicates the involvement of an active mechanism in its translocation.

To study further the nature of the calcium transport process in the superficial pars recta, experiments were performed wherein the tubules were perfused and effluent fluid collected at room temperature. Under these conditions no significant $\mathrm{J}_{\text {net }}^{\mathrm{Ca}}$ could be measured. After bringing the bath temperature up to $37^{\circ} \mathrm{C}$, however, there was a progressive increase in $\mathrm{J}_{\text {net }}^{\mathrm{Ca}}$ reaching at $2 \mathrm{~h}$ a value $50 \%$ of that measured in tubules studied at $37^{\circ}$ promptly after dissection. This observation suggests that the interactive process involved in calcium efflux from this segment depends on cellular metabolism. This was tested in a separate group of experiments in which $10 \mu \mathrm{M}$ ouabain was added to the bathing medium. Although ouabain increased the PD and reduced the Jv near zero, there was only a small decline in $\mathrm{J}_{\text {net }}^{\mathrm{Ca}}$. Thus, inhibition of sodium-potassium-activated ATPase did not seem to affect calcium transport in this segment. This observation raises the possibility that calcium in the tubular lumen may enter the tubular cells down an electrochemical gradient and be transported out at the basolateral membrane by a transporter not inhibitable by ouabain, perhaps a calcium-stimulated ATPase. It is of interest in this regard that Kinne-Saffran and Kinne (17) have localized a calcium-stimulated ATPase in the basolateral plasma membrane of rat cortical proximal tubule. This enzyme, therefore, may play an important role in calcium transport out of the superficial proximal straight tubule of the rabbit. Because it was resistant to known inhibitors (17), the precise role of this enzyme will have to await the identification of specific inhibitors of its activity.

The absence of an effect of ouabain on $J_{\text {net }}^{\text {Ca }}$ appears to be in conflict with the proposal of $\mathrm{Na}$-Ca antiport in the basolateral membrane similar to that proposed for the squid axon (18). Inhibition of $\mathrm{Na}, \mathrm{K}$, ATPase should have raised intracellular sodium and diminished the chemical gradient for sodium entry into the cell thereby impairing calcium efflux. It must be pointed out, however, that in the present studies the tubules were exposed to ouabain for a period not exceeding $50 \mathrm{~min}$. This brief period may not have allowed sufficient time for cellular sodium to increase. Our studies, therefore, cannot be considered to entirely exclude the possibility of a $\mathrm{Na}-\mathrm{Ca}$ antiport in the rabbit straight proximal tubule.

Because the use of isotopic calcium is fraught with difficulties, resulting from its tendency to adhere to glass and to precipitate in alkaline media, questions may be raised about the validity of the foregoing results. However, extreme care was exercised to siliconize all glass surfaces that came in contact with the perfused and collected fluid, and all solutions and oils were equilibrated with $5 \% \mathrm{CO}_{2}$ in order to prevent loss of $\mathrm{CO}_{2}$ and alkalinization of the solutions containing calcium. Further evidence of the validity of our results is the observation that no significant calcium efflux could be measured at room temperature, and that heating the bath partially and gradually restored $\mathrm{J}_{\text {net }}^{\mathrm{Ca}}$. Furthermore, using identical solutions and technics, we measured $\mathrm{J}_{\mathrm{lb}}^{\mathrm{Ca}}$ and $\mathrm{J}_{\text {net }}^{\mathrm{ca}}$ in the thin descending limb of Henle that were insignificantly different from zero, and we calculated a low $\mathrm{Ke}^{\mathrm{Ca}}$ comparable to that previously reported (2). Finally, results almost identical to ours have been reported in a preliminary fashion from another laboratory (19). The weight of the evidence, therefore, supports our findings and conclusions.

In summary, the superficial proximal straight tubule of the rabbit appears to be an important site of net calcium absorption. It exhibits a high efflux coefficient for calcium and appears to transport this ion against an electrical and a chemical gradient. This transport process is not saturated and appears to transport increasing amounts of calcium with increasing load. While it is inhibited by cold, it is not inhibited by ouabain. The exact nature of this transport process will require further elucidation.

\section{ACKNOWLEDGMENT}

This investigation was supported by research grant AM-21394 from the National Institute of Arthritis, Metabolism, and Digestive Diseases, National Institutes of Health, U. S. Public Health Service.

\section{REFERENCES}

1. Lassiter, W. E., C. W. Gottschalk, and M. Mylle. 1963. Micropuncture study of renal tubular reabsorption of calcium in normal rodents. Am. J. Physiol. 204: 771-775.

2. Rocha, A., J. B. Magaldi, and J. P. Kokko. 1977. Calcium and phosphate transport in isolated segments of rabbit Henle's Loop. J. Clin. Invest. 59: 975-983.

3. Imai, M. 1978. Calcium transport across the rabbit thick ascending limb of Henle's loop perfused in vitro. Pflugers Arch. Eur. J. Physiol. 374: 255-263.

4. Shareghi, G. R., and L. C. Stoner. 1978. Calcium transport across segments of the rabbit distal nephron in vitro. Am. J. Physiol. 4: F367-F375.

5. Jamison, R. L., N. Frey, and F. B. Lacy. 1974. Calcium reabsorption in the thin loop of Henle. Am.J. Physiol. 227: 745-751.

6. de Rouffignac, C., F. Morel, N. Moss, and N. Roinel. 1973. Micropuncture study of water and electrolyte movements along the loop of Henle in Psammomys with special reference to magnesium, calcium, and phosphorus. Pflugers Arch. Eur. J. Physiol. 344: 309-326.

7. Schafer, J. A., and T. E. Andreoli. 1976. Anion transport processes in the mammalian superficial proximal straight tubule. J. Clin. Invest. 58: 500-513.

8. Schafer, J. A., S. L. Troutman, and T. E. Andreoli. 1974. Volume reabsorption, transepithelial potential differences, and ionic permeability properties in mammalian 
superficial proximal straight tubules. J. Gen. Physiol. 64: 582-607.

9. Schafer, J. A., S. Troutman, M. L. Watkins, and T. E. Andreoli. 1978. Volume absorption in the pars recta. I. "Simple" active $\mathrm{Na}^{+}$transport. Am. J. Physiol. 234: F332-F339.

10. Kawamura, S., and J. P. Kokko. 1976. Urea secretion by the straight segment of the proximal tubule.J. Clin. Invest. 58: $604-612$.

11. Tune, B. M., and M. B. Burg. 1969. Characteristics of p-aminohippurate transport in proximal renal tubules. Am. J. Physiol. 217: 1057-1063.

12. Tune, B. M., and M. B. Burg. 1971. Glucose transport by proximal renal tubules. Am. J. Physiol. 221: 580-585.

13. Burg, M. B., J. Grantham, M. Abramow, and J. Orloff. 1966. Preparation and study of fragments of single rabbit nephrons. Am. J. Physiol. 210: 1293-1298.

14. Kawamura, S., M. Imai, D. W. Seldin, and J. P. Kokko. 1975. Characteristics of salt and water transport in super- ficial and juxtamedullary straight segments of proximal tubules. J. Clin. Invest. 55: 1269-1277.

15. Kokko, J. P. 1973. Proximal tubules potential difference. Dependence on glucose, $\mathrm{HCO}_{3}$, and amino acids. J. Clin. Invest. 52: 1362-1367.

16. Rocha, A., and J. P. Kokko. 1973. Sodium and water transport in the medullary thick ascending limb of Henle. J. Clin. Invest. 52: 612-623.

17. Kinne-Saffran, E., and R. Kinne. 1974. Localization of a calcium-stimulated ATPase in the basal-lateral plasma membranes of the proximal tubule of the rat kidney cortex. J. Membr. Biol. 17: 263-274.

18. Blaustein, M. D. 1974. The interrelationship between sodium and calcium fluxes across cell membranes. Rev. Physiol. Biochem. Pharmacol. 70: 33-82.

19. Almeida, A. L. J., L. H. Kudo, and A. S. Rocha. 1978. Calcium transport in isolated perfused pars recta of proximal tubule. Abstracts VIIth International Congress of Nephrology. E-16. 